REFLECTIONS:

NEUROLOGY AND

THE HUMANITIES

Section Editor

Anne W. McCammon,

MD, FAAN

David L. Coulter, MD

Correspondence to

Dr. Coulter:

coulterdl@aol.com

\title{
A Child Neurologist's Lament
}

\section{LATE ONE NIGHT IN THE PREMATURE NURSERY}

Seven hundred and ninety-five grams

With joy and excitement you came to your mother,

First fruit of her womb,

Quickening her young motherhood.

Born too small and born too soon,

You could not live in the world of your birth.

Had we withdrawn from you when nature did,

Never-to-be-conscious child,

There might have been mystery in your life,

There would have been dignity in your dying.

But we in our blindness never saw,

Those three long months you lived with us,

Your broken lungs, your damaged brain

Intoxicating our technology,

The tiny infant who would never be,

The suffering child whose hope had failed.

Thirteen hours the family waited,

Eleven hours you took to die,

Finally free of the machine that bound you

To a world you could not call your own.

I kept a quiet vigil by your deathbed

As you slowly slipped so far beyond us

To the timeless darkness outside life.

Little baby, in that leaving

Lives the meaning of your life

And the beauty of a peaceful, well-earned death.

\section{THE BOY WHO MUST DIE}

Two years past you walked and smiled While I labeled you with my diagnosis Of irreversible brain disease.

My efforts useless, it comes to this:

All your years of youth were wasted As your withered life, shriveled too soon, Lingers now on the brink of death.

Your parents in their loving grief, Your doctor in his sad despair, Join you in this hopeless, stubborn vigil At your bedside in the ICU, Asking death to wait a moment While we watch the child we lovedWhere you are going, there is no return.

What is the point of all of this? Is this the reason you were born?

Who can understand the death of a child? Not we, who did all we knew, and failed; Not your friends, now bereft of you, Beloved classmate and partner in play. Least of all the father who conceived your birth, Rejoiced in your youth, his only son and heirTaking for granted his mortal posterity.

Let us enjoy our sons in the days that are given us, Fill our lives with the pleasures of our friends, Yield to perverse time no love or joy, And mourn the person you would have become. 


\section{Neurology}

\section{A Child Neurologist's Lament}

David L. Coulter

Neurology 2015;84;1060

DOI 10.1212/WNL.0000000000001342

\section{This information is current as of March 9, 2015}

\section{Updated Information \& Services}

\section{Subspecialty Collections}

\section{Permissions \& Licensing}

\section{Reprints}

including high resolution figures, can be found at: http://n.neurology.org/content/84/10/1060.full

This article, along with others on similar topics, appears in the following collection(s):

\section{Coma}

http://n.neurology.org/cgi/collection/coma

Neonatal

http://n.neurology.org/cgi/collection/neonatal

Palliative care

http://n.neurology.org/cgi/collection/palliative_care

Information about reproducing this article in parts (figures,tables) or in its entirety can be found online at:

http://www.neurology.org/about/about_the_journal\#permissions

Information about ordering reprints can be found online: http://n.neurology.org/subscribers/advertise

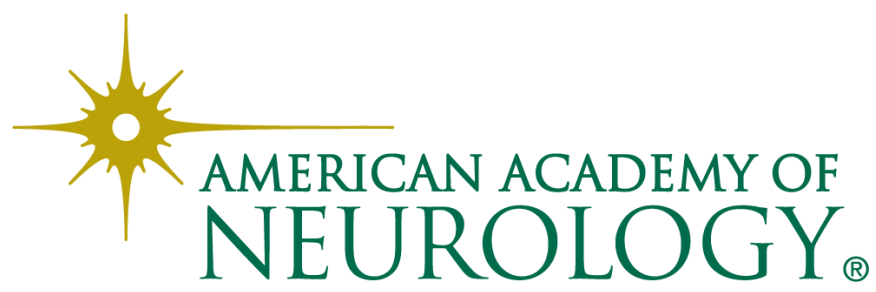

